\title{
THE POLITICS AND LAW OF TRADE UNION RECOGNITION: DEMOCRACY, HUMAN RigHTS AND PRAGMATISM IN THE NEW ZEALAND AND BRITISH CONTEXT
}

\author{
Alan Bogg* and Tonia Novitz ${ }^{* *}$
}

\begin{abstract}
In this article, we seek to examine the potential for cross-fertilisation of legal regimes relating to trade union representation of members in collective bargaining. The United Kingdom has moved from an entirely voluntarist model in the 1980s to a statutory regime which facilitates recognition of a trade union following majority support from workers (usually by a ballot). By way of contrast, New Zealand has shifted from a highly regulated award-based model in the 1980s to an "agency" model whereby an employer is required to bargain in good faith with any union representing two or more of the employer's employees, but with some balloting also contemplated for coverage of non-unionised workers. It is uncontroversial that the United Kingdom legislation has been severely limited in its effects in a context of ongoing decline in collective bargaining, while the New Zealand model offers only faint remediation of the dismembering of the collective bargaining system by the Employment Contracts Act 1991. In both legal systems, a Labour Party is now proposing implementation of forms of sectoral bargaining. We explore the reasons for these political and legal developments, exploring democratic and human rights rationales for their adoption, as well as more pragmatic approaches. In so doing we examine the scope for democratic trade union representation via consent or ballot, the role of individual human rights and regulatory rationales. We conclude by considering how representative and regulatory approaches may be mutually reinforcing and address different understandings of "constitutionalisation". In so doing, we reaffirm the emphasis placed in Gordon Anderson's writings on substance over form.
\end{abstract}

* University of Bristol, United Kingdom.

** University of Bristol, United Kingdom. 


\section{INTRODUCTION}

In this article, we consider the potential for cross-fertilisation of legal regimes relating to trade union representation of members in collective bargaining. The United Kingdom has moved from an almost entirely voluntarist model in the 1980s to a more hybrid statutory-voluntary regime. ${ }^{1}$ The legislation facilitates recognition of a trade union following majority support from workers (usually by a ballot). However, voluntary bargaining arrangements where the parties reach agreement is still given preference. By way of contrast, New Zealand shifted from a highly regulated award-based model to an "agency" model whereby an employer is required to bargain in good faith with any union representing two or more of the employer's employees. It was the latter feature, analogous to common law contractual principles and the law of agency, which Gordon Anderson identified in his extensive writing on this subject. ${ }^{2}$

It is uncontroversial that British legislation has been severely limited in its effects in a context of ongoing decline of collective bargaining coverage, while the New Zealand model offers only faint remediation of the dismembering of the collective bargaining system by the Employment Contracts Act 1991. We examine the reasons for these political and legal developments, considering democratic and human rights rationales for their adoption. Curiously, New Zealand offers a more direct protection of the "right to be represented" often recognised as intrinsic to freedom of association, despite the absence of a juridified "constitutionalisation" framework.

We then explore whether the operationalisation of this "agency" approach could supplement the majoritarian system adopted in the United Kingdom (also Australian and North American) bargaining regimes in ways that are more conducive to an inclusive "bottom up" workplace democracy based upon strong worker mobilisation. This has the potential to provide legal support for "industrial strength", which Gordon Anderson and Pam Nuttall have considered necessary for effective trade union representation as a basis for "voice" at work. ${ }^{3}$

We also address the regulatory challenges posed by the recent turn towards "sectoral" bargaining strategies, as outlined in the recent British Labour Party Manifesto proposals ${ }^{4}$ and New Zealand

1 The United Kingdom consists of Great Britain and Northern Ireland. We use the term "British" colloquially to refer to this full constituency.

2 Gordon Anderson "Good Faith in the Individual Employment Relationship in New Zealand" (2011) 32 Comp Lab L \& Pol'y J 685. See also Gordon Anderson Reconstructing New Zealand's Labour Law: Consensus or Divergence? (Victoria University Press, Wellington, 2011).

3 Gordon Anderson and Pam Nuttall "The Good-Faith Obligation: An Effective Model for Promoting Voice?" in Alan Bogg and Tonia Novitz (eds) Voices at Work: Continuity and Change in the Common Law World (Oxford University Press, Oxford, 2014) 194.

4 The Labour Party For the Many, Not the Few: The Labour Party Manifesto 2017 (2017) at 47 and 51 which states that Labour will "roll out sectoral collective bargaining". 
Labour Party proposals for "Fair Pay Agreements". ${ }^{5}$ We end by reflecting upon how representational and regulatory enterprise-based and sector-based bargaining might be coordinated in an integrated system of multilevel governance in New Zealand and the United Kingdom, alongside how different understandings of "constitutionalisation" can be effective.

\section{II "REPRESENTATIONAL" AND "REGULATORY" BARGAINING THROUGH TRADE UNIONS: INDIVIDUAL RIGHT, DEMOCRATIC ENTITLEMENT, OR PUBLIC GOVERNANCE?}

Keith Ewing and John Hendy have drawn attention to an important distinction between two different conceptions of collective bargaining. ${ }^{6}$ "Representational" bargaining is usually predicated upon the representation of workers' interests through collective bargaining at the level of the enterprise. This form of bargaining is circumscribed in two main respects: first, bargaining outcomes are typically confined to the enterprise; and second, the trade union's representation function is tied very closely to the authorising consent of the represented workers. This decentralised "representational" model has, at various times, been characteristic of the United Kingdom, United States, Canadian and New Zealand models of collective bargaining. There are of course many important legal differences between each of these jurisdictions. There is however an underlying basic normative unity, which is to frame collective bargaining as a private market activity conducted by trade unions on an enterprise basis as designated agents of a tightly circumscribed bargaining unit. In turn, this "representational" conception is closely aligned with a consent-based model of representational legitimacy.

By contrast, a "regulatory" conception of collective bargaining conceives of it as a public regulatory activity conducted at sectoral or national levels. On this view, collective bargaining is a mode of public governance akin to lawmaking. It involves trade unions in the public governance of employment for larger scale geographical or sectoral constituencies. This may even extend to national-level social pacts. This regulatory species of collective bargaining is characteristic of European industrial relations systems such as those of France or Germany. Historically, the British and New Zealand industrial relations systems were also aligned with such a regulatory conception. For example, British bargaining institutions were supported by a range of indirect auxiliary props:

5 See the New Zealand Labour Party's 2017 Election Platform: Labour Party "Backing fair pay and conditions" $<$ www.labour.org.nz>. This states that Labour will be "[i]ntroducing Fair Pay Agreements that set fair, basic employment conditions across an industry based on the employment standards that apply in that industry."

6 See KD Ewing "The Function of Trade Unions" (2005) 34 ILJ 1; and Keith Ewing and John Hendy "New Perspectives on Collective Labour Law: Trade Union Recognition and Collective Bargaining" (2017) 46 ILJ 23. 
machinery for ensuring the compulsory normative effect of qualifying collective agreements, wages councils, fair wages clauses, extension of collective agreements and compulsory arbitration. ${ }^{7}$

Comparative reflection on the recent trajectories of British and New Zealand law and practice provides some interesting perspectives on this distinction. Currently, the legal structures in New Zealand and the United Kingdom represent variations on these models. The New Zealand "agency" model is the purest form of a consent-based model of representational legitimacy, in that the trade union acts as a designated bargaining representative exclusively for its members. There are difficulties entailed in extending its normative effects to workers who have not given the union authorisation to act as their agent. By contrast, the British statutory "democratic entitlement" model makes provision for a democratic procedure based upon "majority rule". Where the trade union representative achieves majority support in the bargaining unit, either through membership density or through a statutory ballot, it is authorised to bargain on behalf of all the workers in the bargaining unit. As we shall see, each of these legal models of "representational" bargaining has significant weaknesses. Having identified those weaknesses, we assess whether a hybrid model of "agency" and "democratic entitlement" might provide a more effective legal structure for representational bargaining at enterprise-level.

We then consider the role of sectoral bargaining as "public governance", which requires a different approach to representational legitimacy and regulatory effectiveness. Union membership density might be one relevant factor to consider in determining whether a trade union is representative. However, a rich variety of representational principles has been deployed alongside union membership density in European industrial relations systems. As Bruno Veneziani has observed, "there is no golden formula for representativeness, valid for all situations and all functions, on the European scene". ${ }^{8}$ These criteria have often evolved organically over long periods of time and in accordance with the internal logics of specific industrial relations systems. Factors that have been treated as relevant principles have included (in addition to union membership density): organisational connections to authoritative national confederations; alignment between the subject matter of negotiation and the trade union's particular functions; and sufficient internal structures to facilitate democratic participation of union members. ${ }^{9}$

7 Alan Bogg and Tonia Novitz "Recognition in Respect of Bargaining in the United Kingdom: Collective Autonomy and Political Neutrality in Context" in Breen Creighton and Anthony Forsyth (eds) Rediscovering Collective Bargaining: Australia's Fair Work Act in International Perspective (Routledge, Abingdon-onThames (UK), 2012) 225 at 227, drawing on Alan Bogg The Democratic Aspects of Trade Union Recognition (Hart Publishing, Oxford, 2009).

8 Bruno Veneziani "The intervention of the law to regulate collective bargaining and trade union representation rights in European countries: recent trends and problems" (1999) 5 Transfer 100 at 128.

9 At 126-130. 


\section{A An Individual Right to Representation}

It has been powerfully argued by Hendy that the right to be represented by a trade union is a fundamental human right. ${ }^{10} \mathrm{He}$ sees this as a right to be accompanied to workplace grievances, to be informed and consulted, but also to have access to collective bargaining through trade union representation. It is well established that there is an internationally recognised right to associate and to be a trade union member. Article 22, para 1 of the International Covenant on Civil and Political Rights (ICCPR) states simply: "[e]veryone shall have the right to freedom of association with others, including the right to form and join trade unions for the protection of his interests." 11 Article 8 of the International Covenant on Economic, Social and Cultural Rights (ICESCR) further reiterates in its first paragraph that the "States Parties" undertake to ensure "the right of everyone to form trade unions and join the trade union of his choice, subject only to the rules of the organization concerned, for the promotion and protection of his economic and social interests". ${ }^{12}$ These are notably rights that apply to "everyone" and do not seem to be dependent on national or transnational norms concerning "worker" or "employment" status. ${ }^{13}$ The link between the entitlement to trade union membership and the promotion and protection of one's interests is significant for the purpose of trade union recognition which enables effective collective representation. It seems to be enough that a worker has joined the trade union for him or her to be represented by it in matters of economic and social concern. Further, given the remainder of the text of art 8 of the ICESCR, it is evident that trade unions are to act freely for these purposes, subject only to certain listed restrictions including, notably, "limitations ... prescribed by law and which are necessary in a democratic society in the interests of national security or public order or for the protection of the rights and freedoms of others". ${ }^{14}$ Indeed, in many respects this text mirrors that of art 11 of the European Convention on Human Rights (ECHR), ${ }^{15}$ which is binding on the United Kingdom as a ratifying signatory, having scope for domestic implementation by virtue of the Human Rights Act 1998.

A familiar dimension of the "constitutionalisation" of labour law is the capacity to view the rights of workers as human rights to be protected through human rights mechanisms internationally,

10 John Hendy Every Worker Shall Have the Right to be Represented at Work by a Trade Union (Institute of Employment Rights, Liverpool, 1998).

11 International Covenant on Civil and Political Rights 999 UNTS 171 (opened for signature 16 December 1966, entered into force 23 March 1976), art 22(1).

12 International Covenant on Economic, Social and Cultural Rights 993 UNTS 3 (opened for signature 16 December 1996, entered into force 3 January 1976), art 8(1)(a).

13 Valerio De Stefano "Non-Standard Work and Limits on Freedom of Association: A Human Rights-Based Approach" (2017) 46 ILJ 185.

14 International Covenant on Economic, Social and Cultural Rights, above n 12, art (1)(c).

15 Convention for the Protection of Human Rights and Fundamental Freedoms (as amended by Protocols No 11 and 14) 213 UNTS 221 (opened for signature 4 November 1950, entered into force 3 September 1953). 
regionally and domestically. ${ }^{16}$ The "agency" model of members-only or explicit consent for bargaining would seem to correspond with this human rights-based model. The right-holder is the individual trade union member. The collective dimension of the right occurs whenever a group of trade union members decide to exercise their individual right collectively together. Given that the human rights entitlement is vested in the individual, it follows that this entitlement cannot be extinguished where a trade union fails to achieve majority support in the bargaining unit. This would be a significant advantage in a system based exclusively on majority bargaining agents, where the failure to achieve majority support means that the possibilities for collective representation are effectively extinguished.

Despite its advantages, there are three main difficulties with this model. First, it does not necessarily allow for the possibility that the trade union itself, as a distinct entity, might enjoy a group right to collective bargaining that is separate from the aggregate of individual members' rights. This notion of a collective right to bargain has now been recognised under various constitutional instruments. ${ }^{17}$

Secondly, this model does not provide a clear account of which correlative duties, if any, correspond to the right to representation. The most minimal account might conceive of this as simply a freedom to negotiate through a bargaining agent. In which case, it might follow that since this is simply a freedom, not a right, there are no correlative duties on employers. Of course, Hendy's argument identifies the basic entitlement as a right to representation. This transcends the limitations of a simple agency model and might connect to the bargaining "in good faith", which Anderson identified as vital to any success of the New Zealand system of industrial relations. ${ }^{18}$ It still leaves unresolved however whether correlative duties escalate where these individual rights are exercised collectively, for example allowing for the scope to extend collective bargaining coverage to a minority of non-trade union members.

Finally, in many human rights instruments there is an important principle of effective legal protection that shapes the implementation of human rights guarantees. For example, under the ECHR the European Court of Human Rights (ECtHR) has stated that "the Convention is intended to guarantee not rights that are theoretical or illusory but rights that are practical and effective". ${ }^{19}$ In a system of members-only bargaining, where bargaining arrangements are so fragmented as to provide

16 See Judy Fudge "Constitutionalizing Labour Rights in Canada and Europe: Freedom of Association, Collective Bargaining, and Strikes" (2015) 68 CLP 267.

17 See for example the Constitution of the Republic of South Africa 1996, art 23(4) and (5).

18 Anderson and Nuttall, above n 3.

19 Artico v Italy (1981) 3 EHRR 1 (ECHR) at [33]. 
a weak system of worker representation, this may constitute a failure to ensure that worker representation arrangements are "practical and effective".

It is notable that these provisions in the ICCPR and ICESCR are expressly linked to International Labour Organization (ILO) Convention No 87, which is to take precedence in terms of state obligations. ${ }^{20}$ The difficulty, perhaps, with ILO Convention No 87 is that trade union recognition falls somewhere between art 2, which again sets out the bare entitlement of workers to form and join trade unions and art 3 which enables workers to "organise their administration and activities and to formulate their programmes". In this sense, ILO Convention No 98 offers a vital supplement to these modest statements of basic human rights by placing an obligation on states to promote collective bargaining. Here art 4 is vital, which states that: ${ }^{21}$

\footnotetext{
Measures appropriate to national conditions shall be taken, where necessary, to encourage and promote the full development and utilisation of machinery for voluntary negotiation between employers or employers' organisations and workers' organisations, with a view to the regulation of terms and conditions of employment by means of collective agreements.
}

At this point, we have arguably moved beyond the individual entitlement model. Where there is state responsibility to ensure that collective bargaining is promoted, this requires that members-only arrangements be supplemented by other forms of positive legal support for trade union representation.

\section{B A Democratic Claim to Representation}

In arguing for a democratic right to representation, one is seeking to overcome the objection that, while a person has a human right to join a trade union, the ability of that union to request that an employer engages in collective bargaining is subject to limitations. In particular, the worker's right can be viewed as being limited by (inter alia) the rights and freedoms of the employer, the latter being "necessary in a democratic society" (as set out in art 8 of the ICESCR and art 11(2) of the ECHR). In this context, employers have sought to argue that they have the right not to be a trade union member and a right not to engage in collective bargaining. ${ }^{22}$ The counterargument is that where the workers'

20 International Covenant on Civil and Political Rights, above n 11, art 22(3); and International Covenant on Economic, Social and Cultural Rights, above n 12, art 8(3).

21 Indeed, it would seem to be from Convention No 98 that art 23(4) and (5) of the Constitution of the Republic of South Africa are derived.

22 See for example, Young, James and Webster v United Kingdom (1982) 4 EHRR 38 (ECHR); and Gustafsson $v$ Sweden (1996) 22 EHRR 409 (ECHR). See Tonia Novitz "Negative Freedom of Association" (1997) 26 ILJ 79; and Virginia Mantouvalou "Is there a Human Right Not to Be a Trade Union Member? Labour Rights under the European Convention on Human Rights" in Colin Fenwick and Tonia Novitz (eds) Human Rights at Work: Perspectives on Law and Regulation (Hart Publishing, Oxford, 2010) 439. For a more recent illustration, see Janus v American Federation of State County, and Municipal Employees 585 US 16-1466 (2018). The majority judgment effectively abolishes "agency fees" paid by non-members for union-led improvement in their terms and conditions, which was fixed at approximately 78 per cent of full union dues, 
desire to be so represented is itself collectively determined and democratic in nature, it offers a powerful reason for state-supported "recognition". In both an Australian and British context, legislative intervention has given weight to this understanding of recognition as a democratic claim. However, concerns remain as to their operation: from the ways in which numbers are tallied (is this genuine "democracy"?), ${ }^{23}$ to the scope of obligations (after recognition) to bargain in good faith. ${ }^{24}$

The legislative scheme in the United Kingdom reflects the general structure and normative orientation of the National Labor Relations Act 1935 (United States Wagner Act) model. ${ }^{25}$ It empowers a specialist agency, the Central Arbitration Committee (CAC), to determine the bargaining unit and measure worker support within that bargaining unit. The CAC must impose (absent a voluntarily agreed method), a legally binding bargaining procedure agreement upon the parties in a situation of majority worker support for the union's recognition claim. This mechanism is based upon a conception of representational legitimacy that collective bargaining rights are legitimated through the collective majoritarian consent of workers. In simple terms, workers get collective bargaining only if this is what workers want, and the state remains neutral as to those preferences. Collective consent is determined by a process of preference aggregation. This usually occurs through a formal ballot, although it is still possible in the United Kingdom for majority support to be confirmed through trade union membership levels in the bargaining unit. Where the union achieves majority support, "democratic" models of union recognition generally confer exclusive representative status on that union in respect of the bargaining unit.

In the United Kingdom, at least, human rights jurisprudence under art 11 of the ECHR has provided some modest support to the statutory recognition model. In Wilson $v$ United Kingdom, the ECtHR held that United Kingdom law had violated art 11 because: $^{26}$

... it was open to the employers to seek to pre-empt any protest on the part of the unions or their members against the imposition of limits on voluntary collective bargaining, by offering those employees who acquiesced in the termination of collective bargaining substantial pay rises, which were not provided to those who refused to sign contracts accepting the end of union representation.

overturning a 40 year precedent. See the dissenting judgment of Justice Kagan, with whom Justice Ginsberg and Justice Sotomayer joined.

23 Bogg, above $\mathrm{n}$ 7, at chs 5 and 7.

24 Anthony Forsyth and Sara Slinn "Promoting Worker Voice through Good Faith Bargaining Laws: The Canadian and Australian Experience" in Alan Bogg and Tonia Novitz (eds) Voices at Work: Continuity and Change in the Common Law World (Oxford University Press, Oxford, 2014) 165. Compare Anderson "Good Faith in the Individual Employment Relationship in New Zealand", above n 2, at 685.

25 See the Trade Union and Labour Relations (Consolidation) Act 1992 (UK), sch A1.

26 Wilson v United Kingdom (2002) 35 EHRR 20 (ECHR) at [47]. 
As such, the United Kingdom government was under an obligation to introduce measures to protect trade unionists from the use of financial inducements which interfered with the art 11 rights of individual workers and the trade union itself. Such intervention would provide an important prop to the bargaining activities of an exclusive bargaining agent, by supporting the "normative effect" of collectively agreed norms in the bargaining unit.

Wilson was an important staging post in the evolution of a progressive art 11 jurisprudence. At this stage, the ECtHR stopped short of recognising a right to collective bargaining as an essential element of art $11 .{ }^{27}$ In the landmark decision in Demir and Baykara $v$ Turkey, ${ }^{28}$ the Court finally recognised the right to collective bargaining as a fundamental element of art 11 . In the course of so doing, the Court observed that this recognition was in the context of "it being understood that States remain free to organise their system so as, if appropriate, to grant special status to representative trade unions". ${ }^{29}$ This opened up permissive space under art 11 for a statutory system that conferred preferential bargaining rights, correlative to bargaining duties, on majoritarian bargaining representatives, so as to comply with obligations under ILO Convention No 98.

\section{Public Governance}

As we have seen, proposals for sectoral arrangements now form part of a progressive agenda for collective bargaining reforms in New Zealand and the United Kingdom. It is worthwhile to reflect upon the position of such arrangements from the perspective of human rights jurisprudence. As Ewing and Hendy have pointed out in their recent reflections on sectoral collective bargaining, sectoral arrangements were effectively blocked in the United States because of constitutional objections. ${ }^{30}$ This was because the achievement of binding normative effect for sectoral codes, secured through a presidential order, gave these codes the status of law. This was constitutionally objectionable because lawmaking authority had been allocated to Congress under the United States constitution. Ewing and Hendy also point to recent jurisprudence in Ireland where similar constitutional objections were levelled against sectoral arrangements. ${ }^{31}$ This is an important reminder that human rights, understood as legal entitlements in the hands of the courts, can sometimes obstruct the realisation of progressive political agendas.

Given the prevalence of sectoral bargaining in Europe, art 11 is unlikely to be interpreted by the ECtHR so as to undermine sectoral arrangements. There is not a single constitutionalised template for

27 At [44].

28 Demir and Baykara v Turkey (2009) 48 EHRR 54 (Grand Chamber, ECHR). See KD and John Hendy "The Dramatic Implications of Demir and Baykara" (2010) 39 ILJ 2.

29 Demir and Baykara v Turkey, above n 28, at [154].

30 Ewing and Hendy, above n 6, at 32.

31 At 32 . 
the right to collective bargaining. Rather, the right will take shape in a variety of ways across different constitutional orders. Nevertheless, we think that there are three potential difficulties in reconciling a constitutionalised right to collective bargaining with sectoral arrangements.

First, art 11 has operated as a weak constraint on the deregulation of sectoral arrangements in the United Kingdom. In Unite the Union $v$ United Kingdom, the ECtHR considered that the abolition of the Agricultural Wages Board did not constitute an interference with the right to collective bargaining under art $11 .{ }^{32}$ Accordingly, the application was rejected as manifestly ill-founded. The abolition of the sectoral scheme was within the state's margin of appreciation. The ECtHR regarded it as significant that other mechanisms for securing recognition existed, such as industrial action or the statutory recognition procedure. Given that in agriculture the vast majority of employers fail to meet the stipulated threshold of employing at least 21 workers, the statutory recognition procedure is in practice unavailable within the agricultural sector. In addition, the dispersed and often precarious nature of employment in the sector rendered it highly unlikely that groups of co-workers would be able to secure recognition through a credible threat of strike action. Indeed, it is these very reasons that provided the rationale for a protective sectoral regime. ${ }^{33}$

Secondly, in order for sectoral institutions to operate effectively, it is necessary that trade unions can organise strike action on a sectoral basis. This would require some latitude for trade unions to organise "secondary" industrial action, in other words, action taken in support of other workers, when one's own employer is not a party to the original dispute. In United Kingdom law, the statutory immunity for strike action is withdrawn in circumstances of "secondary" action. This leaves the trade union exposed to liability in tort, and it exposes individual strikers to a greater risk of lawful dismissal for participating in strike action. The ban on secondary action was challenged in National Union of Rail, Maritime and Transport Workers $v$ United Kingdom. ${ }^{34}$ The ECtHR rejected the application as inadmissible, on the basis that the domestic ban was justified under art 11 and within the state's margin of appreciation.

Both decisions demonstrate that art 11 may be impotent in the face of legislative action hostile to sectoral arrangements. The third possibility is that constitutional freedom of association norms might themselves be presented as a constitutional barrier to sectoral arrangements. We have already seen this phenomenon in the United States and Irish contexts. In the recent Canadian case of Mounted Police Association of Toronto v Canada (Attorney General), the Supreme Court of Canada concluded that a statutorily imposed non-independent representative body constituted a "substantial interference"

32 Unite the Union v United Kingdom [2016] ECHR 1150.

33 At [65].

34 National Union of Rail, Maritime and Transport Workers v United Kingdom [2014] ECHR 366. See also Alan Bogg and KD Ewing "The Implications of the RMT Case" (2014) 43 ILJ 221. 
with employees' freedom of association. ${ }^{35}$ In its reasoning, the Court referred to the significance of "choice" in assessing the constitutional propriety of labour relations arrangements, namely the ability "to have effective input into the selection of the collective goals to be advanced by their association". ${ }^{36}$ It is important to emphasise that this decision was crafted within the specific context of the Canadian constitution. Nevertheless, the constitutionalisation of "choice" as a normative principle seems to be aligned with a "democratic mandate" model of union recognition and even collective action. ${ }^{37}$ Since representational legitimacy extends beyond "choice" in sectoral arrangements, such a principle could create constitutional difficulties for sectoral collective bargaining.

\section{SEPARATE HISTORIES: SOME STARTING POINTS FOR COMPARISON}

Our experience of the "Voices at Work" project, on which we were engaged with Gordon Anderson as one of our research partners, has made us wary of crude comparisons between different national industrial relations systems. ${ }^{38}$ We do not pretend that trade union recognition has ever meant the same in the British and New Zealand systems. Rather, both can be understood as shaped by their respective histories.

The British trade union recognition system operates against the background of "collective laissezfaire" bargaining and unsuccessful experimentation with forms of state intervention in the 1970s. Whereas, the New Zealand system is deeply rooted in a history of extensive state intervention in the apparatus for collective bargaining, a 30-year rejection of that model which has proved unsuccessful and a new determination to experiment with combinations of past approaches which benefit working people.

\section{A From Collective Laissez-faire to "Democratic" Trade Union Recognition in the United Kingdom}

The United Kingdom has, in industrial relations terms, followed its own distinctive trajectory towards recognition of organised labour and scope for collective bargaining. Historically, the United Kingdom system was based upon the theory and practice of "collective laissez-faire". This eschewed a reliance on "direct" methods of legal enforcement, such as a legal duty to bargain. Instead, collective

35 Mounted Police Association of Ontario v Canada (Attorney General) [2015] 1 SCR 3.

36 At [83].

37 For comparison of the "democratic" rationales for United Kingdom rules on majority voting for statutory trade union recognition and the ability to take industrial action in "important public services" (namely approval by 40 per cent of those eligible to vote), see Tonia Novitz "UK regulation of strike ballots and notices - Moving beyond 'democracy'?" (2016) 29 AJLL 226.

38 For an overview of the project (2011-2014), see generally Alan Bogg and Tonia Novitz "Purposes and Techniques of Voice: Prospects for Continuity and Change" in Voices at Work: Continuity and Change in the Common Law World (Oxford University Press, Oxford, 2014) 3, especially at [5]. 
bargaining was promoted through a variety of "indirect" (or auxiliary) methods such as institutionbuilding through administrative law, fair wages resolutions and public contract compliance, extension mechanisms for collective agreements, compulsory arbitration and sectoral wages councils. ${ }^{39}$

The first legislative experiment in "direct" trade union recognition was implemented in the illfated Industrial Relations Act 1971. This legislation offered trade unions certain new forms of statutory protection and the promotion of their interests, but in exchange for registration, which entailed a highly juridified restriction of their freedom to undertake strike action. The recognition procedure was short-lived. The entire legislative framework was rendered unworkable by a concerted campaign of non-registration by most British trade unions. The second legislative experiment in statutory recognition was implemented in the Employment Protection Act 1975 and was administered by the Advisory, Conciliation and Arbitration Service (ACAS). This procedure also ended after a brief and unhappy life, but for different reasons. The low point was reached in Grunwick Processing Laboratories Ltd v Advisory Coalition and Arbitration Service, where the employer had refused to cooperate with either the trade union or ACAS in a disputed recognition case. The House of Lords considered that ACAS could not recommend recognition without a full investigation, even when the reason for the lack of such an investigation was obstruction by the employer motivated by bitter employer hostility to the unionisation of the workforce. ${ }^{40} \mathrm{In}$ fact, a series of damaging judicial review cases had impeded the discretionary work of ACAS to such an extent that the legislation became very difficult to administer. ${ }^{41}$

The current statutory procedure is set down in the Trade Union and Labour Relations (Consolidation) Act 1992, sch A1 and has been in operation since 2000. In its most recent annual report, the CAC indicated that there had been only 51 applications for trade union recognition in 2016-2017, a figure which has remained relatively steady in recent years. ${ }^{42}$ The impact of sch A1 has therefore been rather marginal, both in respect of union recognition secured directly under the legislation and union recognition secured through "voluntary" means. ${ }^{43}$

We think that there are several reasons for this pattern. One, which emerged in respect of the controversy over the abolition of the Agricultural Wages Board, is the requirement that there be a 21

39 See Bogg, above $\mathrm{n} 7$, at ch 1 .

40 Grunwick Processing Laboratories Ltd v Advisory Coalition and Arbitration Service [1978] 1 All ER 378 (HL).

41 Bogg and Novitz "Recognition in Respect of Bargaining in the United Kingdom: Collective Autonomy and Political Neutrality in Context", above n 7, at 227.

42 Central Arbitration Committee Annual Report 2016/17 (23 June 2017).

43 See Gregor Gall "Book Review: Statutory Regulation and Employment Relations: The Impact of Statutory Trade Union Recognition" (2014) 43 ILJ 218. 
worker threshold for the statutory system to apply. ${ }^{44}$ There is also the point made powerfully by Anne Davies that part-time workers only count as "half" under this system, so that the threshold may be even more difficult to meet. ${ }^{45}$ Further, the very threshold of "worker" is currently difficult to satisfy in the context of the "gig economy". A clause inserted by the employer into food couriers' contracts which enabled them to find substitutes to carry out tasks for them was found to defeat a claim for statutory recognition. ${ }^{46}$ Moreover, "the winner takes it all", with there being no scope for membersonly bargaining orders or for an individual to insist on being represented by a trade union where the union fails to secure a majority. There is a problem of a simple "non-union default", ${ }^{47}$ exacerbated by significant limitations on the "unfair practice" constraints set out in the legislation.

The domestic courts have sometimes used art 11 of the ECHR to provide a purposive construction of certain elements of the statutory scheme. For example, in Netjets Management Limited v Central Arbitration Committee the High Court considered the appropriate interpretation of the territorial jurisdiction of British statutory provisions by reference to art 11. In this respect, Supperstone J observed that: ${ }^{48}$

The reality is that if the union cannot bargain collectively with the claimant in relation to their pay, hours and holidays in Great Britain they will not be able to exercise their art 11 right.

In Vining v London Borough of Wandsworth, the exclusion of "parks constables from the scope of the statutory redundancy consultation scheme was regarded as a violation of both their and their union's art 11 rights. ${ }^{49}$ Such exclusions from statutory schemes required a justification, and no justification had been offered on the facts of the case. ${ }^{50}$ This might have a wider significance for the appeal currently being brought on behalf of gig economy workers.

However, the Court of Appeal in Pharmacists' Defence Association Union v Boots Management Services Ltd declined to issue a "declaration of incompatibility" in a situation where the employer had

44 See $n 32$ and associated text.

45 ACL Davies "'Half a Person': A Legal Perspective on Organizing and Representing 'Non-Standard' Workers" in Voices at Work: Continuity and Change in the Common Law World (Oxford University Press, Oxford, 2014) 122 at 122.

46 See Independent Workers' Union of Great Britain (IGWB) v RooFoods Limited TA/ Deliveroo Central Arbitration Committee TUR1/985(2016), 14 November 2017. Upheld on judicial review by Supperstone J in $R$ (on the application of the Independent Workers' Union of Great Britain) $v$ Central Arbitration Committee and Roofoods Ltd t/a Deliveroo [2018] EWHC 3342 (QB).

47 Mark Harcourt and others "A Union Default: A Policy to Raise Union Membership, Promote the Freedom to Associate, Protect the Freedom not to Associate and Progress Union Representation" (2018) 48 ILJ 66.

48 Netjets Management Ltd v Central Arbitration Committee [2012] EWHC 2685 (Admin) at [42].

49 Vining v London Borough of Wandsworth [2017] EWCA Civ 1092, [2018] ICR 499.

50 At [65]. 
recognised a non-independent trade union which blocked the statutory application of a competing independent trade union. ${ }^{51}$ The Court of Appeal took the view that it was sufficient that an individual worker could petition for a derecognition ballot under the legislation, and that the detailed implementation of the "right to recognition" was a matter of balance for the legislature. ${ }^{52}$ Overall, the role of art 11 in relation to the United Kingdom statutory scheme might be described as "mostly harmless". ${ }^{53}$ It has sometimes provided modest purposive support to the statutory scheme at the margins. More significantly, perhaps, art 11 has not been used by the courts to frustrate the statutory scheme, in the manner of the English courts under the 1975 Employment Protection Act statutory recognition scheme in the United Kingdom. ${ }^{54}$

As matters stand (in the midst of this complex statutory and rights-based matrix), the rate of British unionisation and collective bargaining coverage is in decline. Union membership has fallen from a peak of 65 per cent (approximately 13 million employees) in 1980 to 23.5 per cent in 2016 (approximately 6.2 million employees). There has been a decrease of 8.9 per cent even since 1995.55 Membership is eroding in both the private and public sectors. In the private sector, membership declined in 2015-2016 for the first time in six years and stands only at 13.4 per cent, while in the public sector it is now 52.7 per cent. In 2015-2016 both declined in a way which has been described as "statistically significant". ${ }^{56}$ This can be contrasted with previous growth in public sector trade union membership from 1995-2005 and stability until 2010. ${ }^{57}$ This correlates broadly to collective bargaining coverage, which stands in the public sector at 57.6 per cent, while only 15.2 per cent of employees in the private sector had their pay and conditions negotiated by a union. Over the past 20 years, the percentage for the public sector has dropped by 16.8 per cent and in the private sector by eight per cent. ${ }^{58}$ The result seems to be that rates of pay are lowering and terms and conditions worsening, especially in particularly vulnerable sectors of the economy, such as that concerned with

51 Pharmacists' Defence Association Union v Boots Management Services Ltd [2017] EWCA Civ 66, [2017] IRLR 355, as discussed in Alan Bogg and Ruth Dukes "Article 11 ECHR and the Right to Collective Bargaining: Pharmacists' Defence Association Union v Boots Management Services Ltd" (2017) 46 ILJ 543.

52 Pharmacists' Defence Association Union v Boots Management Services Ltd, above n 51, at [67]-[68].

53 Douglas Adams The Hitchiker's Guide to the Galaxy (Pan Books, London, 1979).

54 See nn 40-41 and associated text.

55 Mark Cully and others Britain at Work: As Depicted by the 1998 Workplace Employee Relations Survey (1999) at 235-242; and Department for Business, Energy and Industrial Strategy Trade Union Membership 2016: Statistical Bulletin (May 2017) at 3.

56 Department for Business, Energy and Industrial Strategy, above n 55, at 5.

57 At 12 .

58 Statista "Collective agreement coverage in the United Kingdom (UK) 1996-2017, by sector" $<$ www.statista.com>. 
adult social care. ${ }^{59}$ In other words, the United Kingdom is facing regulatory failure in various sectors of its labour market.

Unsurprisingly, the result in the British Labour Party has been to propose radical reform of collective bargaining mechanisms. The Institute of Employment Rights (IER) - a think tank for policymaking linking trade unions with academic specialists in labour law and industrial relations in 2016 launched A Manifesto for Labour Law, which advocated a new Ministry of Labour and new "machinery for the development of sector wide standards". ${ }^{60}$ The Manifesto proposed that "ultimately every worker and every employer of workers in this country should be covered by a collective agreement concluded at the sectoral level", ${ }^{61}$ a call which follows from previous IER policy proposals and publications. ${ }^{62}$ Sectoral Employment Commissions set up by the Ministry of Labour would "promote collective bargaining and ... regulate minimum terms and conditions of employment within specific industrial sectors". ${ }^{63}$ These proposals have been welcomed by the current British Labour Party leadership, which in the most recent Labour election manifesto made a commitment to create a Ministry of Labour and "review the rules on union recognition so that more workers have the security of a union". ${ }^{64}$ Further, the British Labour Party would, in its "20-point plan", "roll out sectoral collective bargaining - because the most effective way to maintain good rights at work is collectively through a union". ${ }^{65}$ At present, however, the United Kingdom has a Conservative Government held in place by a precarious confidence and supply agreement with the Democratic Unionist Party in Northern Ireland. There is accordingly no immediate prospect of implementation of these policy proposals and no way to know how they would fare under a human rights review by the domestic courts or the ECtHR.

59 See Lydia Hayes 8 Good Reasons Why Adult Social Care Needs Sectoral Collective Bargaining (Institute of Employment Rights, Liverpool, 2017).

60 KD Ewing, John Hendy and Carolyn Jones (eds) A Manifesto for Labour Law: Towards a Comprehensive Revision of Workers' Rights (Institute of Employment Rights, Liverpool, 2016) at [3.12]. See also ch 3, especially at 20. We should add that the authors of this article are also contributors to this publication.

61 At [3.13].

62 KD Ewing and John Hendy Reconstruction after the crisis: a manifesto for collective bargaining (Institute of Employment Rights, Liverpool, 2013); and Lydia Hayes and Tonia Novitz Trade unions and economic inequality (Institute of Employment Rights and CLASS, London/Liverpool, 2014).

63 See Ewing, Hendy and Jones, above n 60, at [3.13] and 20-21.

64 The Labour Party, above n 4, at 46.

65 At 47 and 51. 


\section{B New Zealand Shifts from State Control to Individual Agency and on to Sectoral Bargaining?}

In terms of the New Zealand experience, the Industrial Conciliation and Arbitration Act 1894 (IC\&A) offered a highly regulated system of collectively negotiated "awards" which operated in particular sectors. The IC\&A therefore operated in stark contrast to British "collective laissez faire", although it does not look so very dissimilar to the proposals of the current British Labour Party.

Anderson and Nuttall have attributed the IC\&A system more to New Zealand trade unions' political as opposed to industrial strength. ${ }^{66}$ This was a legislative solution which aided trade unions when the bitter 1890 maritime strike ended with victory for the employers. In the United Kingdom, trade unions were (at least at that time) stronger and could, without state support, engage in significant regulation of workers' treatment in the workplace.

Initially, parties could include "union membership clauses" in awards or agreements, with the First Labour Government introducing compulsory trade union membership in 1936 (with limited conscience clauses and an exception for the public service). ${ }^{67}$ Awards covered all workers in a particular industry, with effectively monopoly unions engaged both in representing workers in the IC\&A system and subsequently enforcing the awards in the workplace. ${ }^{68}$ At this stage, there was almost complete trade union membership among the workforce, but the extent to which unions effectively represented their members was questioned by some commentators. ${ }^{69}$ A "New" Labour Government, pursuing "Rogernomics" and what has been described as a "neo-liberal" economic agenda abolished compulsory arbitration ${ }^{70}$ and later introduced the Labour Relations Act 1987, which made provision for collective bargaining outside the traditional structure of awards and registered collective agreements, allowing for "enterprise" level bargaining at workplaces. ${ }^{71}$ Only registered trade unions with over 1,000 members could claim the enhanced representation and negotiation rights within the national awards structure. ${ }^{72}$

66 Anderson and Nuttall, above n 3, at 195.

67 See discussion in Tonia Novitz "New Zealand Industrial Relations and the International Labour Organisation: Resolving Contradictions in Freedom of Association" (1996) 21 NZJIR 119 at 125.

68 Anderson and Nuttall, above n 3, at 197.

69 Martin Gross "The Condition of New Zealand Trade Unions" [1961] NZJPA 28; and Noel Woods "Comments on the Industrial Conciliation and Arbitration Act 1894" (1994) 19 NZJIR 225, as cited in Anderson and Nuttall, above $\mathrm{n}$, at 197.

70 Industrial Relations Amendment Act 1984, as cited in Anderson and Nuttall, above n 3, at 198.

71 Novitz "New Zealand Industrial Relations and the International Labour Organisation: Resolving Contradictions in Freedom of Association", above n 67, at 127.

72 Labour Relations Act 1987, s 6. 
By 1991, a newly elected National Government had introduced the Employment Contracts Act, which entirely abolished the past system of union registration alongside any remnants of the IC\&A system. Instead, workers and their employers could authorise "bargaining agents" (who could be any person or organisation) to conclude employment contracts on their behalf, whether individual or collective. Notably, even established trade unions would not necessarily constitute workers' bargaining agents, regardless of historical patterns of representation. The number of workers covered by a collective agreement dropped swiftly (by approximately 45 per cent). ${ }^{73}$ While the Employment Relations Act 2000 was introduced to ameliorate that damage, the agency model for union representation remains much the same and collective bargaining coverage has never recovered. ${ }^{74}$

The 2000 legislation introduced a duty to deal in "good faith"75 and the sole right of trade unions to negotiate collective employment contracts for their members. ${ }^{76}$ Further, the duty of good faith "requires a union and an employer bargaining for a collective agreement to conclude a collective agreement unless there is a genuine reason, based on reasonable grounds, not to". ${ }^{77}$ That genuine reason cannot include opposition or objection in principle to "bargaining for, or being a party to, a collective agreement" or "including rates of wages or salary in a collective agreement" or "disagreement about including a bargaining fee clause" but currently may include "opposition to concluding a multi-employer collective agreement ... if that opposition is based on reasonable grounds". ${ }^{78}$ In cases of a breach of the duty to bargain in good faith, the New Zealand Employment Relations Authority may impose all or part of a first contract. ${ }^{79}$

Moreover, there are parts of the Employment Relations Act (as amended) that look less like an exercise of the individual right to trade union representation and more like a United Kingdom "democratic" mechanism. An example is the provision in s 45 which contemplates a secret ballot to be held by the union in the situation where there is either " 1 union proposing to initiate bargaining with 2 or more employers for a single collective agreement" or "2 or more unions proposing to initiate bargaining with 1 or more employers for a single collective agreement" (or where the union suspects

73 Novitz "New Zealand Industrial Relations and the International Labour Organisation: Resolving Contradictions in Freedom of Association", above n 67, at 129.

74 Pam Nuttall "Collective Bargaining and Good Faith Obligations in New Zealand" in Breen Creighton and Anthony Forsyth (eds) Rediscovering Collective Bargaining: Australia's Fair Work Act in International Perspective (Routledge, Abingdon-on-Thames (UK), 2012) 290 at 292.

75 Employment Relations Act 2000, ss 4 and 32.

76 Employment Relations Act, s 40.

77 Employment Relations Amendment Act 2018, s 14, replacing the Employment Relations Act, s 33.

78 Employment Relations Amendment Act, s 14, replacing the Employment Relations Act, s 33.

79 On grounds listed in subs (3) of the Employment Relations Act, s 50J, as discussed by Harcourt and others, above n 47, at 24 . 
that there may be opposition to the employer's proposal for a single collective agreement). ${ }^{80}$ More recently, legislative provision for "bargaining fees", introduced by the Employment Relations Amendment Act (No 2) 2004, also entails a secret ballot if agreed by the employer and union. Part $6 \mathrm{~B}$ has enabled an employer and union to conduct a joint ballot of non-unionised employees, prior to any collective agreement coming into force, to see if non-union members would be prepared to pay the "bargaining fee" to make the union their agent and be covered by the collectively negotiated terms. If there is majority support in the ballot, then all non-union members can come within the coverage clause of the collective agreement, unless an individual chooses on a personal basis not to pay the bargaining fee. ${ }^{81}$ An employer cannot undermine the collective agreement by passing on identical terms to non-union members otherwise.

It should be observed that "collective employment agreements" are legally binding in a very different way to the United Kingdom, where the norm is for only those terms "incorporated" into individual employment contracts to be legally enforceable. ${ }^{82}$ Also, under the Employment Relations Act, anyone who joins a union automatically joins the corresponding collective agreement that covers his or her work. ${ }^{83}$

However, the legislative changes since 1991 have not led to notably enhanced outcomes. New Zealand continues to have one of the lowest rates of collective bargaining coverage in the Organisation for Economic Co-operation and Development (OECD) at under 20 per cent, with links to lower wages and higher income inequality. ${ }^{84}$ Like the United Kingdom, New Zealand has witnessed in the 2010 "Hobbit legislation" the systemic and arguably even more deliberate exclusion of certain persons from "worker" status and, thereby, collective bargaining rights. ${ }^{85}$

80 Employment Relations Act, s 45 and following. A secret ballot was also envisaged as part of transitional measures regarding the continuation in force of collective agreements after repeal of the Employment Contracts Act 1991 by virtue of ss 243 and 246 of the Employment Relations Act.

81 Employment Relations Act, s 69R(2), as discussed by Nuttall, above n 74, at 304.

82 Trade Union and Labour Relations (Consolidation) Act 1992 (UK), s 179. See also Ford Motor Co Ltd v Amalgamated Union of Engineering and Foundry Workers [1969] 2 QB 303 (QB); and on "aptness for incorporation" Malone v British Airways plc [2010] EWCA Civ 1225, [2011] IRLR 32 at [52].

83 Employment Relations Act, ss 18 and 56, as discussed by Harcourt and others, above n 47, at 23.

84 New Zealand Council of Trade Unions "Submission to the Education and Workforce Committee on the Employment Relations Amendment Bill 2018" at 13. See also Organisation for Economic Co-operation and Development "Collective bargaining coverage" OECD.Stat <https://stats.oecd.org> which says that the number of employees in New Zealand with the right to bargain in 2016 lay at 16 per cent.

85 See Employment Relations (Film Production Work) Amendment Act 2010, as discussed in Bernard Walker and Rupert Tipples "The Hobbit Affair: A New Frontier for Unions?" (2013) 34 Adel L Rev 65. See also Pam Nuttall "'...Where the Shadows Lie': Confusion, misunderstanding, and misinformation about workplace status" (2011) 36(3) NZJER 73; and Margaret Wilson "Constitutional Implications of 'The Hobbit' Legislation" (2011) 36(3) NZJER 91. 
However, changes are taking place. In April 2017, the then Prime Minister the Rt Hon Bill English (with cross-party support) announced a \$2 billion pay equity settlement for care and support workers in New Zealand aged and disability residential care and community support services. ${ }^{86}$ A new pay scale was introduced in the sector which raised the minimum wage from NZD 15.75 per hour to NZD 19 per hour - a 21 per cent rise. This addressed concerns in a vulnerable employment sector noticed also in the United Kingdom. ${ }^{87}$ The Labour-led coalition Government (led by the Rt Hon Jacinda Ardern) has indicated that this care and support workers settlement should be regarded as the beginning of a roll out of Fair Pay Agreements on a sectoral level. ${ }^{88}$ A Fair Work Agreement Working Group representing various aspects of the political spectrum and diverse industrial and expert actors was established to carry the plan forward and has now reported back, so the New Zealand Government is still considering the options. ${ }^{89}$ In response, the National Party, now in opposition, along with BusinessNZ, have said that, if introduced, when back in office they will abolish Fair Pay Agreements, since they will take New Zealand back to sectoral strikes (although of course what we know of the awards system is that they managed to suppress strikes for a considerable period). ${ }^{90}$ Indeed, it is already contemplated that strikes will not be permitted in respect of such agreements. ${ }^{91}$ Arguably, this new policy stance takes New Zealand beyond a human rights or "representational" collective bargaining framework as issues of "regulatory" efficacy become more relevant.

Further, we note that, at the time of writing, amendment of the "Hobbit law" is anticipated, such that the right to engage in collective negotiations will be restored. Again, a working group (including a variety of social actors including BusinessNZ and the New Zealand Council of Trade Unions) has recommended changes that balance film industry and workers' protections. ${ }^{92}$ This suggests a shift to

86 Care and Support Workers (Pay Equity) Settlement Agreement (1 July 2017); and for media comment: Isaac Davidson and Claire Trevett "Government announces historic pay equity deal for care workers" The New Zealand Herald (online ed, Auckland, 18 April 2017).

87 Hayes, above n 59.

88 Doug Martin "Fair Pay Agreements-Issues and challenges for a new wave of collective bargaining" (1 May 2018) Medium <https://medium.com>.

89 Hon Iain Lees-Galloway "Government's Fair Pay Agreement work to begin" (press release, 5 June 2018). See also as at 12 June 2019, the statement of "Fair Pay Agreements" made by the Ministry of Business, Innovation and Employment: Ministry of Business, Innovation and Employment "Fair Pay Agreements" $<$ www.mbie.govt.nz>.

90 Newshub "National promises to scrap government's Fair Pay Agreement plans" (6 June 2018) $<$ www.newshub.co.nz>.

91 Lucy Bennet "A ban on industrial action a feature of Government's new Fair Pay Agreements" The New Zealand Herald (online ed, Auckland, 5 June 2018).

92 Shane Cowlishaw "'The Hobbit Law' - there and back again" (30 January 2018) Newsroom $<$ www.newsroom.co.nz>. 
enabling broader collective bargaining coverage for non-standard work, which does have a flavour of the human right to be represented by a trade union.

\section{FINAL REFLECTIONS ON THE "VIRTUOUS CIRCLE" BETWEEN REPRESENTATIONAL AND REGULATORY BARGAINING MODELS AND THE NATURE OF "CONSTITUTIONALISATION"}

We wish to conclude by stressing that there is no necessity to choose between "representational" or "regulatory" bargaining models. Indeed, we believe that there are significant advantages in a democratic system of collective bargaining that provides simultaneous support to enterprise and sectoral bargaining. In this respect, we agree with Ewing and Hendy that: ${ }^{93}$

... the extension of collective bargaining is not simply about the expansion of horizontal measures for sectoral standard setting, but also for simultaneously deepening vertical enterprise based trade union activity, vertical in the sense that the trade union role should be embedded from the cloakroom to the boardroom. The two (the horizontal and the vertical) should be highly integrated.

Rather, we think that this multi-level approach can create a "virtuous circle" of solidaristic practices. Strong union organisation in the enterprise provides legitimacy and support to the maintenance of sectoral bargaining. Strong sectoral bargaining reduces the scope for employers to challenge the legitimacy of enterprise-based unionism, and it reduces the economic incentives for union exclusion and avoidance. It might therefore be possible to marry regulatory sectoral bargaining with majoritarian recognition in enterprise bargaining, as well as agency options for multi-union workplaces where otherwise recognition would be unavailable.

The achievement of this "virtuous circle" requires patient work to ensure that these bargaining arrangements are effectively aligned and efficiently coordinated. Still, the matter of effective coordination is not solely a matter of regulatory design. We should acknowledge that there are two potential sources of normative friction between "representational" and "regulatory" bargaining in any integrated system. The first lies in the role and function of democratic arguments; and the second lies in the facilitative or obstructive role of a constitutionalised human rights frame.

From the perspective of "democracy ", in "representational" bargaining the principal normative focus is on ensuring that the bargaining representative has democratic legitimacy. Discussions are directed at the nature of the consent or balloting mechanisms, the specification of support thresholds, the circumstances in which ballots might be dispensed with, alternative methods for gauging majority support and so forth.

For "regulatory" bargaining, by contrast, legitimacy requires a wider consideration of the performance outcomes of governance arrangements. This has been described as "performance

93 Ewing and Hendy, above n 6, at 42 (footnotes omitted). 
legitimacy" in Neil Walker's rich account of governance legitimacy. ${ }^{94}$ "Performance legitimacy" is focused upon the ability of governance processes to deliver good policy outcomes. ${ }^{95}$ This would require a consideration the objective qualities and characteristics of the representative organisation and its ability to perform an effective role in the formulation and implementation of policy goals. Veneziani for example identifies "the scope of the union's professional constituency, its affiliation to a national union and its functional and structural suitability". ${ }^{96}$ This assessment of the organisation's attributes from the perspective of "performance legitimacy" encompasses a multiplicity of factors that might include: financial resources; research capacities to gather and interpret relevant economic data; integration with national and transnational trade union confederations; organisational independence from employers; a history of bargaining in a particular sector, indicating suitability and special expertise; and effective internal participatory structures to facilitate the democratic input of members. All these factors provide an indication of the trade union's actual bargaining capabilities, namely the capacity to make a genuine difference which adds value to workers' agreed terms and conditions.

Secondly, we may wish to reflect on the role of constitutionalised rights in facilitating or impeding bargaining structures. Constitutional jurisprudence in Canada and under the ECHR has undergone a transformation following the constitutional recognition of the right to bargain collectively and the right to strike under the Canadian Charter of Rights and Freedoms and the ECHR. ${ }^{97}$ These rights are now treated as protected under general freedom of association guarantees. On the face of it, a jurisdiction like New Zealand might appear to be at a distinct disadvantage in missing out on this constitutional wave. However, we have seen that in the United Kingdom as elsewhere, constitutional rights have operated sometimes as impediments to the wider ambit of trade union organisation, as indeed they have done in other judicial contexts. This is no more than a recognition that constitutionalised labour rights, protected through constitutional courts, sometimes bring losses as well as gains for working people. We might also wish to remember that "constitutionalisation", just like "democracy", can be understood in a multiplicity of ways.

Ruth Dukes has described the "constitutional function" of labour law as harnessing law to institute, or "recognize a system of workers' councils and bi-partite industrial councils, and to confirm the

94 Neil Walker "The White Paper in Constitutional Context" in Christian Joerges, Yves Mény and JHH Weiler (eds) Mountain or Molehill? A Critical Appraisal of the Commission White Paper on Governance (Jean Monnet Working Paper No 6/01, 2001).

95 Neil Walker, above n 94, at 33, as discussed in Tonia Novitz and Phil Syrpis "Assessing Legitimate Structures for the Making of Transnational Labour Law: The Durability of Corporatism" (2006) 35 ILJ 367 at 369-370; and Alan Bogg "The Death of Statutory Union Recognition in the UK" (2012) 54 JIR 409 at 417-418.

96 Veneziani, above $\mathrm{n}$ 8, at 129

97 Fudge, above n 16. 
continued existence of the trade unions and employers' associations". ${ }^{98}$ In so doing, she conceives of constitutionalisation in terms of institutions, constitutional structures for worker participation and democratic outcomes. In this respect, she eschews a narrow preoccupation with juridical form focused on fundamental rights guarantees in a written constitution.

If New Zealand proposals to institute sectoral Fair Pay Agreements are successful, the New Zealand system may yet represent an exemplar of a constitutionalised and democratic system of labour law that produces equitable social and economic outcomes. Paradoxically, perhaps, this will have been achieved in a system lacking constitutionalised labour rights in the sense of a legally enshrined human rights paradigm (even if this is manifested in its "agency model"). However, bearing in mind Dukes' fuller sense of "constitutionalisation" in the sense of institutional social justice, this may indeed be achieved. This triumph of democratic substance over democratic form would be a fitting testament to the very same themes that characterise Gordon Anderson's reflections on collective bargaining laws in New Zealand and beyond.

98 Ruth Dukes "Hugo Sinzheimer and the Constitutional Function of Labour Law" in Guy Davidov and Brian Langille (eds) The Idea of Labour Law (Oxford University Press, Oxford, 2011) 57 at 62. See also Ruth Dukes The Labour Constitution: The Enduring Idea of Labour Law (Oxford University Press, Oxford, 2014). 